\title{
The "Scaene of Elysium": Painters, Plaintiffs and Paradise in John Dryden's Tyrannick Love (1669)
}

\author{
Claudine van Hensbergen
}

\begin{abstract}
This article examines surviving evidence related to the work of three leading artists who painted scenery for the Restoration stage: Isaac Fuller, Robert Streater [Streeter] and Robert Robinson. Taking as its starting point Allardyce Nicoll's account of the Restoration stage in his influential 1923 History of English Drama, the article argues that our knowledge of Restoration theatre scenery remains in need of new methodologies that are not based solely on evidence derived from printed play texts. Using Dryden's Tyrannick Love (1669) as a case study, I will show how legal accounts, surviving artworks produced for other sites and wider contemporaneous sources point to the complexity and quality of some scenes. Such scenery could play an active role in producing the meaning of a dramatic work, making it wholly understandable why the theatre companies made substantial financial investment in certain cases.
\end{abstract}

\section{Keywords}

John Dryden, Tyrannick Love, heaven, painting, scenery, Isaac Fuller, Robert Streater [Streeter], Robert Robinson

This article was supported by the Czech Science Foundation project GA19-07494S. English Theatre Culture 1660-1737. 
In June 1669, Dryden's tragedy Tyrannick Love, or The Royal Martyr was staged at the Theatre Royal in London. It was a major success, running for fourteen days. The play starred Peg Hughes as Saint Catherine and Nell Gwyn as Valeria, the tragic daughter of the Roman emperor Maximinus whose predatory sexual advances are rebuffed by Catherine, leading to her martyrdom. Dryden claimed to have written the play in seven weeks. Despite this speed, it was staged almost two months later than intended. The cause of this delay was a piece of painted scenery - an "Elysium" produced by Isaac Fuller, and it led to a series of court cases in which Thomas Killigrew and his leading actors claimed the delayed performance meant that they had lost out on a further $£ 500$ of projected income. ${ }^{1}$ In his 1923 History of English Drama, Allardyce Nicoll argued extensively about the important role of scenery in public theatre of the Restoration, drawing our attention to the "wondrous panoramas" presented on stage (NICOLL 1923: 44). Scenery had long been important to the court masque but, as James Wright's 1699 history of the stage, Historia Histrionica, informs us, it was a new innovation on the public stage that arrived during the early years of the Restoration (WRIGHT 1699: 10-11). Richard Flecknoe wrote of the "present heighth [sic] of magnificence" in decoration and setting which made plays "more for sight, then hearing" (FLECKNOE 1664: [8]). And the epilogue to Dryden and Howard's Indian Queen, first performed in 1664, drew attention to its lavish scenery, commenting on the opportunities it presented for audience members to display their wit:

'Tis true, y'have Marks enough, the Plot, the Show,

The Poet's Scenes, nay, more, the Painter's too;

If all this fail, considering the Cost,

'Tis a true Voyage to the Indies lost.

(The Indian Queen, DRYDEN and HOWARD 1665: [175])

In this case, the money seems to have been well spent: John Evelyn noted the "rich scenes" (EVELYN 1901: 1: 372) of this same production.

Much as Nicoll did to proclaim the importance of painted scenery and other visual forms on stage, he was disparaging of this feature of Restoration drama:

The spectators could appreciate fine things, both in comedy and in tragedy, but they were also swayed by external ephemeral things of no value or permanent consequence. For this latter reason, the arts which may be called contributory to the drama, and which, in all great productions, should be rendered subservient to the characters and to the dialogue, grew to assume a larger and larger place in the reigns of Charles II and of James. (NICOLL 1923: 28)

Nicoll's assumption that contributory arts - such as painting and music - should be rendered subservient to the characters and dialogue remains influential to this day.

1 This equates to approximately $£ 57,000$ of today’s money. Calculation made using National Archives Currency Converter. Available online at https://www.nationalarchives.gov.uk/currency-converter/ [accessed 12 December 2020]. 
Furthermore, studies that have sought to reinstate the importance of the visual, most notably Judith Milhous's 1984 essay on the Restoration multimedia spectacular, have perhaps limited the scope of those productions that scholars conceive of as reliant on spectacle; Milhous influentially suggested that there were only eight 'machine plays' that took the visual to newly successful heights (MILHOUS 1984). Indeed, studies and editions of Restoration drama tend to pay relatively little attention to the ways in which the play text or its staging relates to visual elements. As a result, we persist in holding a skewed understanding of what actually unfolded on the stage, imposing our own ideas about dramatic value and hierarchy upon a production rather than understanding it on its own terms. Tim Keenan's recent study of Restoration staging has sought to redress this imbalance, by exploring the question of scenery in detail by drawing on a range of visual documents and stage directions recorded in play texts (KEENAN 2017; see also BAKEWELL 2016). But such texts were largely produced for reading purposes, and include varying and often scant indications of scenic information. Regrettably, only a small number of illustrative prints and drawings are extant from the period. The latter sources are documented in Keenan's study, including the most cited example of Restoration scenery for the public stage: William Dolle's engravings for The Empress of Morocco, produced for William Cademan's lavish 1673 edition of Elkanah Settle's play. John Webb's drawings of scenery designs for The Siege of Rhodes and Tragedy of Mustapha for the Whitehall Theatre in the 1650s and 1660s also provide an excellent insight into the ways in which scenery was used on the court stage, likely influencing its use in the public theatres.

For all the work that has been done by Keenan and other scholars to resituate the importance of the visual to the Restoration stage, no study has attempted to approach this subject through a consideration of the artists involved in painting scenes for the theatre. This is an approach made difficult, of course, because the primary materials (the scenes themselves) are lost. Due to its ephemeral nature, scenery from the Restoration period and eighteenth century does not survive. The earliest known survival of painted scenery in Britain is "The Woodland Scenery" at Richmond's Georgian Theatre Royal, which dates to a century and a half later. ${ }^{2}$ But the relationship between painters and their theatrical scenes is one that can be recovered in other ways, not least through legal cases that make this relationship visible. Nicoll identified six artists who painted for the stage: Robert Aggas (or Angus), Robert Streater, Stevenson (or Stephenson), Samuel Towers, Isaac Fuller and Robert Robinson. In part, their involvement has remained visible due to documented legal disputes. Yet there has been little attempt to focus attention on these painters. This is a fact made more surprising since, as Nicholl states, the amounts asked for by painters, and in particular the sum claimed by Fuller, "amply demonstrate the importance scenery had assumed" (NICOLL 1923: 42). Nicoll made this argument in the footnotes to his history of the theatre, and this is where this discussion has remained ever since. The present article argues for the

2 Images of Richmond's "Woodland Scenery" can be viewed online at https://www.vam.ac.uk/blog/ news/behind-the-scenery-at-the-georgian-theatre-royal-richmond [accessed 17 December 2020]. 
central role of Fuller's painted scenery for a specific production, Dryden's Tyrannick Love, with this serving as a case study for a wider appreciation of the role scenery played in Restoration theatre. Scenery, I argue, was not just a backdrop but could be central to the production and meaning of a play, and we need to do much more work to understand the extent to which this was the case. Much in the same way that historians of music have argued persuasively for music's central role on the Restoration stage, we need to find new methodologies for recovering the theatrical role of the visual arts. I want to suggest that one way in which we can start to do this is through consideration of the artists involved in painting scenes for the stage. As I show, beyond surviving legal documentation, attention to the wider careers of these artists can help us to make informed assessments of how their other outputs might relate to their painted scenes for the theatre. Despite the relative obscurity of these artists today, the list of men who painted for the stage include some of the leading artists of their day, and members of the London Guild Company of Painter Stainers. By placing new focus on the relationship of three of these artists (Fuller, Streater and Robinson) to the stage, I show how a consideration that centres on visual evidence and wider creative outputs can shed new light on our appreciation of their work for the theatre. In this process, we begin both to glimpse how sophisticated their painted scenes likely were, and to understand their crucial role in the production of plays by leading dramatists like Dryden.

\section{Isaac Fuller and Dryden's Tyrannick Love (1669)}

Isaac Fuller (1606/20?-1672) was one of the leading artists of Restoration England, working both in Oxford and London. He is best remembered as the artist of a sequence of five scenes that depict Charles II's escape into exile in 1651, now held at the National Portrait Gallery, London. ${ }^{3}$ Fuller also produced portraits, but in his own lifetime was known chiefly as a practitioner of 'history painting' (a term used in the period for decorative or mural painting). ${ }^{4}$ Evidence of Fuller's professional involvement with the theatre lies solely in surviving legal documentation relating to his aforementioned work for Killigrew on Dryden's Tyrannick Love. On 26 January 1670 Fuller petitioned the Lord Chamberlain for $£ 250$ of unpaid funds from this work. He recouped some $£ 33510$ s, to include the $£ 40$ he had been paid on account (NOVAK and GUFFEY 1970: 546). This was not, however, the end of this affair. In response, a Chancery suit was launched against him in June 1671 by Killigrew and his theatre's leading actors, Charles Hart and Charles Mohun. ${ }^{5}$

The Chancery case documentation consists of several thousand words, yet even a brief summary provides a fascinating insight into the importance of Fuller's single

3 For a discussion of these works see (SOLKIN 1999: 199-240; ROGERS 1979: 164-169).

4 For an excellent recent study of mural painting see (HAMLETT 2020).

5 A complete transcription of the case is given as an appendix, Chancery Suit Concerning Scenery for Tyrannick Love', 6-16 June 1671 (NOVAK and GUFFEY 1970: 539-547). This case is also recorded in (MILHOUS and HUME 1991: 115). 
painted scene. The case records how the actors Charles Hart and Michael Mohun; "were appointed by your orator Thomas Killigrew to treat \& agree with the said Isaac Fuller touching his painting of the said Scaene of Elysium [...] upon or about the Fourteenth day of the said moneth of Aprill one thousand six hundred sixty nine" (cited in NOVAK and GUFFEY 1970: 539).

The document states that the parties agreed that:

\begin{abstract}
Fuller shold paint the said Scaene of Elysium of such largenes as should fitt the stage of the said house or Theater Royall and that he should paint the same so well as other Scaenes belonging to the said Theatre were usually painted by other painters and as was fitting for the same to be painted for the best advantage of the said Tragedy, [and] that he shold soe paint $\&$ perfect the same within a fortnight then next following. (cited in NOVAK and GUFFEY 1970: 539)
\end{abstract}

The plaintiffs go on to allege that Fuller "did wilfully neglect \& delay the painting \& perfecting of the said Scaene till the latter end of June", and due to a "distast" caused by this delay the king and other patrons forbore attending other productions at the theatre (NOVAK and GUFFEY 1970: 540).

According to the plaintiffs, worse was to follow. When the scene was eventually delivered, it was

painted very meanly \& inconsiderably \& not at all answearable to what became such a play or to the curiosity wherewith the said Isaack Fuller agreed to paint the same, by reason whereof the said play when it was Acted was disparaged \& lost its reputation \& not halfe the company resorted to see the acting thereof which wold have come in case the said Scaene had byn painted according to the said Agreement. (NOVAK and GUFFEY 1970: 541)

As a result, the plaintiffs claimed that "the painting \& finishing of the said Scaene not being worth Fifty pounds whereas if the same had byn painted according to the said Agreement the painting \& finishing thereof wold have byn worth as much more." In total, the theatre claimed to be damaged to the extent of "five hundred pounds at least" by Fuller's breach of agreement, and hoped that Fuller would make them some recompense for their loss, the more so as they had paid him $£ 40$ on account. But Fuller had made no such recompense, rather bringing an "action att law against your Orators Charles Hart and Michaell Moone [Mohun] for painting \& finishing the said Scaene $\&$ hath recovered three hundred thirty five pounds ten shillings against them for the same" (NOVAK and GUFFEY 1970: 541).

The second part of the document records Fuller's own evidence, presented on 16 June 1670. Fuller relates how "One Mr. Dryden (a Poett as this Defendant hath heard that Sometimes makes Playes [for] the Company of Comedians or Actors in the Bill mentioned) and one Mr. Wright (a Joyner belonging to the Said Company)" came to visit him to arrange for the commission (NOVAK and GUFFEY 1970: 543). This shows that Dryden took a personal involvement in the commission, presumably describing 
what was needed for the scene, whilst Wright explained the technicalities. Fuller goes on to claim that there was never an agreement made that the scene should be finished within the fortnight, an act "in truth impossible" for any artist to achieve. He recalls that the theatre complained that they had lost money not just due to the delay, but also due to the poor quality of the final product. He provides counter evidence that expert opinion had thought the scene well-executed:

noe painter in England could have finished the same and have done the worke Soe well as this Defendant did it in Soe Short a Space. For that att the tryall att Law hereafter mentioned [...] One Mr. Streeter an eminent Paynter beeing pduced by the now plaintiffs themselves as a wittnesse on their behalf, did acknowledge that this Defendant had a quicker hand att painting then any other, And if hee Pformed the Said Worke in Six weekes time it was very fayre, And did also acknowledge that the Saide worke was excellently well done. (NOVAK and GUFFEY 1970: 544)

Fuller notes that public opinion confirmed this expert view:

The testimony of Wittnesses produced by this Defendant as also by wittnesses produced by the plantiffs themselves, Some of them beeing their own Servants, that the said Scaene was very well paynted and gave great content to the Spectators that came to see the said Play Acted And that the plaintiffs and their said Company acted the Same about 14 dayes together and received all that while about 100 li. per diem Whereas at other playes they are not wont usually to receive above 40 or 50 li. per diem. (NOVAK and GUFFEY 1970: 545)

In summary then, the Chancery document is revealing as it helps us to understand a number of things relating to the role of scenery in theatrical productions of these years. First, scenery was not always just a backdrop that could be casually reused, but something that needed to be tailored to the specific demands of a production. In these cases, it was a key part of the performance, consulted on by dramatists and set designers. Second, the Chancery case shows us the sheer scale of the monies involved in some of these painted scenes. Fuller is paid a total of c. $£ 37510$ s, a huge sum for the day (over $£ 42,700$ in today's equivalent money). ${ }^{6}$ To put this in perspective, a century later Garrick would pay the artist Philip James de Loutherbourg $£ 500$ for a year’s work of designing stage scenery (ROSENFELD 1973: 62). It is worth noting that legal documentation survives showing that Fuller's contemporaries Robert Aggas and Samuel Towers twice petitioned the King's Company for work done at the Theatre Royal; on 8 August 1677 they petitioned for the sum of $£ 40$; on 2 December 1682 they submitted a petition for $£ 32$ (MILHOUS and HUME 1991: 199, 233). Taking into account the status of artists involved in these documented legal cases, we see that the painting of theatrical scenery was not always an amateur art. It involved leading artists, and it shows us

6 Currency conversion made using the National Archives Currency Converter tool, available online at https://www.nationalarchives.gov.uk/currency-converter/ (accessed 9 November 2020). 
how varied the commissions were for those who specialised in 'decorative' or history painting during these years. Indeed, Fuller painted the interiors of churches, Oxford colleges, London taverns and the theatre, as well as portraits on canvas for individual clients. Some decades ago, Sybil Rosenfeld noted the "eminence" of scene painters for the early Georgian stage, whose numbers included James Thornhill and Francis Hayman, and included figures who were "often also decorators of stately homes or public buildings" (ROSENFELD 1973: 60). But Rosenfeld did not trace this pattern back to the Restoration, where the use of leading artists continued just as had been the case in the Caroline period, providing an important link between the operations of Inigo Jones and contemporaneous artists including John de Critz and Edward Pierce, and later eighteenth-century artists like de Loutherbourg.

\section{The Elysium's Central Role in Tyrannick Love}

Despite their claim that they had lost $£ 500$ by delaying the performance, Killigrew and his colleagues chose to delay the play's premiere until Fuller's Elysium was ready. This suggests the importance of the painted scene, both as an investment but also as a spectacle necessary to achieving the intended performance of Act IV Scene 1 of Tyrranick Love, in which the "scene of Paradise is discovered" (The Tyrannick Love, 150). ${ }^{7}$ Although it is lost, we can recover some insights into the scene's material and design. Since the commission was for a scene to fit the whole of the stage, it was surely painted on cloth, making it easy to change the scene quickly, and also easy to transport from Fuller's studio. Michael Liversidge has noted that Fuller had produced work on cloth for other sites, including Oxford's Wadham College Chapel where he had used a cutting-edge approach in employing a two-tone brown and white encaustic process patented in 1636 by the artist Richard Greenbury for use in painting upon "woollen cloth, kerseys, and stuffs, being prop. for hangings" (LIVERSIDGE 1992: 319). Liversidge describes the now-lost cloth altar painting for Wadham as unique in Fuller's oeuvre, and whilst it seems unlikely that he used this technique for the scene of Elysium it would have had clear advantages for storage and subsequent reuse on the stage. Either way, it gives us a sense of Fuller's innovative approach as an artist and the experimental nature of his work at this time.

Crucial evidence indicating the Elysium's design, and its significance to the play as a whole, can be found in the play text. In his 1988 article exploring the occult elements of the play, Jack Armistead sought to disrupt the dominant scholarly account of this scene as "window dressing" that had little relation to the rest of the play proper. Instead, Armistead argued for its relationship to the wider play and Dryden's fuller engagement with ideas of the occult (ARMISTEAD 1988: 367). Yet Armistead did not reference the painted Elysium, or its crucial role within this scene, which would have added further weight to his arguments. Despite the scene's relative brevity at around 73 
lines of text, it is evident that this was the play's central scene. In it, Nigrinus conjures the astral spirits Nakar and Damilcar, commanding them to show a sleeping Catherine dreams that will entice her to accept Maximin's suit. However, the "scene of Paradise" that unfolds corresponds not with Nakar and Damilcar's efforts, but rather with Catherine's minds-eye: the scene is "discovered" as Placidius remarks that "Some pleasing objects do her mind employ; | For on her face I read a wandring Joy" (Tyrannick Love, 151). The painted Elysium that descends is, then, a direct insight into the world that Catherine experiences in her sleep, through which we glimpse the heavenly world waiting for her. By appreciating that vision, the audience could better understand the Christian piety that governs Catherine's actions and her overzealous enthusiasm for her own martyrdom.

In sum, the short Elysium scene involved a song by Damilcar, followed by a song and dance by spirits. Catherine's guardian angel, Amariel, then descends from the air to soft music, delivering his speech before clearing the stage of the pagan presence by waving his flaming sword. The Elysium presumably fell to obscure the shutters of the scene's initial setting in an Indian cave, a scenic work that had already gained renown. The cave was reused from Dryden's earlier tragedy The Indian Emperor (1665), and Keenan presumes this was first made for Dryden's Indian Queen (1664). As Keenan notes, such evidence of the material connection between plays is scarce, but shows that the company took "the opportunity to recycle the expensive new scenery and costumes made specifically for the earlier play" (KEENAN 2017: 126). An argument for the Elysium scene's centrality to the play as a whole is not based purely upon the high financial investment in Fuller's painting, but also because the Elysium's referentiality is felt throughout the play. Indeed, in Act IV we arrive at the destination referenced from the play's outset. For example, Catherine's conversion of the Heathen Philosopher Apollonius in Act II Scene I involves a lengthy discussion of Heaven which ends in the philosopher's conversion and a reaffirmation of his heavenly destination:

S. Cath. [To Apollonius] Lose not that Courage which Heav'n does inspire;

But fearless go to be baptiz'd in fire.

Think 'tis a Triumph, not a danger near:

Give him your blood; but give him not a tear.

Go, and prepare my Seat: and hovering be

Near that bright space which is reserv'd for me. (The Tyrannick Love, 134)

Catherine's speeches refusing Maximin's advances are also peppered by images of Heaven. Here, she chooses death and a heavenly crown over the Egyptian, and then Roman, crowns offered by her would-be-lover:

Placid. Madam, I from the Emperour am come

T'applaude your Vertue, and reverse your doom.

He thinks, whatever your Religion be,

This Palm is owing to your constancy. 
S. Cath. My constancy from him seeks no renown;

Heav'n, that propos'd the course, will give the Crown.

Placid. But Monarchs are the Gods Vicegerents here;

Heav'n gives rewards; but what it gives they bear:

From Heav'n to you th' Egyptian Crown is sent,

Yet 'tis a Prince who does the gift present. (The Tyrannick Love, 137-138)

In her meeting with Maximin immediately after the Elysium scene in Act IV Scene I, Catherine again invokes Heaven, describing herself as "Heav'ns Embassadour" (158), claiming she has been sent by Heaven to restore peace to his empire. Her vision of Elysium has, it seems, inducted her into a new role and is, quite literally, the place from which she has just returned.

This referentiality extends further still, and is registered from the play's preface right through to its epilogue. Dryden's preface suggests the crucial nature of this scene and its painted effect. In defending himself against charges that the stage was not a fitting vehicle for instructing divinity, he argues that:

By the Harmony of words we elevate the mind to a sense of Devotion, as our solemn Musick, which is inarticulate Poesie, does in Churches; and by the lively images of piety, adorned by action, through the senses allure the Soul: which while it is charmed in a silent joy of what it sees and hears, is struck at the same time with a secret veneration of things Celestial, and is wound up insensibly into the practice of that which it admires. (The Tyrannick Love, 109)

The scene of "things Celestial" is referenced again directly upon the play's end, albeit in a more secular way. In her celebrated epilogue, in which Nell Gwyn rose from the dead to address the audience, Gwyn takes us back to Catherine's Elysium as glimpsed during her slumbers in Act IV Scene I:

Gallants, look to't, you say there are no Sprights;

But I'le come dance about your Beds at nights.

And faith you'l be in a sweet kind of taking,

When I surprise you between sleep and waking. (The Tyrannick Love, 192)

Gwyn's reference to a different type of heaven has, ironically, become the most celebrated scene of Dryden's play.

In summary, the painted Elysium performed a range of functions in Dryden's play, allowing us to perceive the reason behind the heavy investment in Fuller's painted scene, and a reason for why Dryden personally consulted with the painter in commissioning the work. Whilst extant scholarship makes it clear that certain scenes were fairly common, with "Eliziums, Heavens and Hells" (NICOLL 1923: 40) occurring frequently in plays, Fuller's Elysium must have been something well beyond the standard fare for such works. In light of this, perhaps the most important question to pose is that of how Fuller attained this sense of distinction, so important to comprehending 
Catherine's desire for martyrdom in Dryden's play? In attempting to answer such a question, we might consider whether the intended effect would have been one similar to those scenes of the heavens painted in the period for the ceilings and walls of palaces and great houses. After all, Fuller was most widely known as a painter of decorative, or "history", scenes. At the Theatre Royal, Fuller surely was not embarking on anything quite as grand as work undertaken on private estates. Yet we should recall that Fuller was paid hundreds of pounds for the scene and, as he testified, had spent over $£ 100$ in materials and servants to produce the work (NOVAK and GUFFEY 1970: 546). Here, one useful point of comparison lies in the work of Antonio Verrio. Fuller was working on the very cusp of Verrio's arrival on English shores in 1672. It was only then that Baroque mural painting began to be more widely introduced in Britain, following the earlier example of Reuben's murals for the Banqueting Chamber at Whitehall and Thomas de Critz and Edward Pierce's work at Wilton House. ${ }^{8}$ Verrio's most significant early commission in England was at Windsor Castle, where he painted fourteen ceilings between 1675 and 1678, and was paid between $£ 50$ to $£ 300$ for each, as well as "his $\mathrm{Ma}^{\text {ties }}$ Free Guift to him [of $£ 200$ ] for his Extraordinary service and Care in Painting the Ceilings of the Kings and Queens Lodgings and some other works about $\mathrm{y}^{\mathrm{e}}$ buildings" (CROFT-MURRAY 1962: 54). By 1684 Verrio would finish his commissions for Windsor, having also decorated the King's Chapel and St. George's Hall, his most ambitious work on site and for which he was paid respectively $£ 1,050$ and £1,250 (CROFT-MURRAY 1962: 54). The sums paid to Verrio for the majority of the ceilings at Windsor were less than that paid to Fuller for his Elysium, and they appear to have been produced at a roughly similar speed in the first phase of the project (three to four per year on average). Only three of these ceilings now remain, including one produced for the Queen's Audience Chamber, in which Catherine of Braganza is presented as the central figure, sitting in a golden chariot in the heavens and surrounded by allegorical figures (Fig. 1). Might this have been a similar scene experienced by Dryden's Catherine? Fuller's Elysium may well have employed a similar type of design, especially in light of the fact that he had trained in France under François Perrier (1590-1650). Perrier was celebrated for his large-scale decorative work for church interiors and altarpieces, and had also had as his pupil Charles Le Brun. It was Le Brun who designed the famed decorative schemes for Louis XIV at Versailles from which Verrio is thought to have taken his chief inspiration at Windsor.

Unfortunately, it is very difficult to properly assess Fuller's wider output as a point of comparison for the painted Elysium since only a few fragments of his own decorative painting survives. These fragments are extant in the form of Fuller's "Resurrection" decorative scheme made for above the altarpiece of All Souls Chapel, Oxford (Figs. 2-5). Within decades of its completion, the work had been removed from the chapel and was thought lost, but it was rediscovered in the college's timber store in the 1950s (DOWNES 1960). Whilst the fragments are in poor condition, they reveal Fuller's rela-

8 For an account of de Critz and Pierce's work at Wilton House and also their collaboration with Inigo Jones for court masques see (CROFT-MURRAY 1962: 39). 


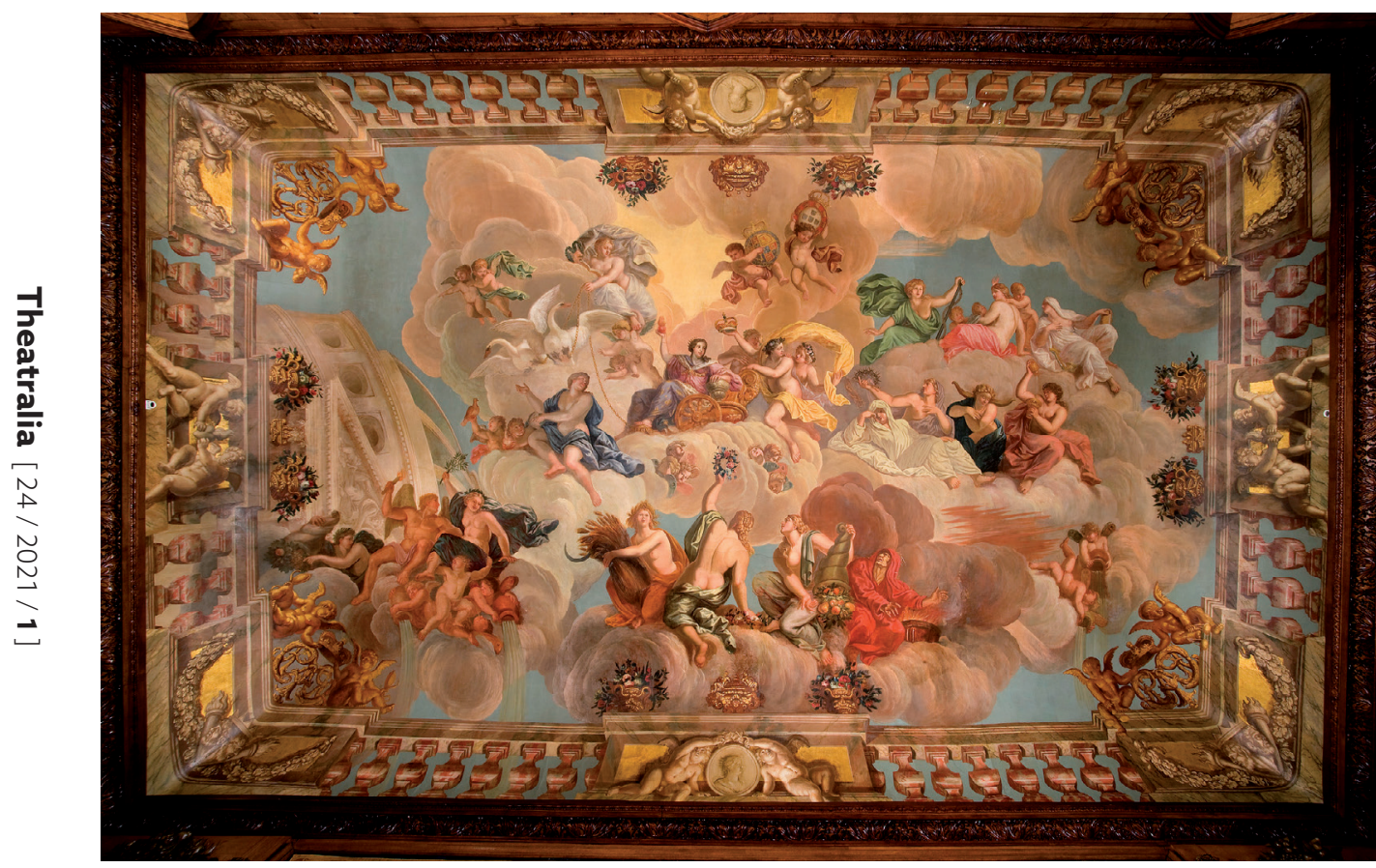

Fig. 1: Antonio Verrio, Catherine Braganza in a Chariot, 1675-c.1684, Queen's Audience Chamber, Windsor Castle, Royal Collection, RCIN 408426.

(c) Her Majesty Queen Elizabeth II 2020.

tive skill at handling perspective in a way that would have also been necessary to his work on the Elysium. Bainbrigge Buckeridge praised this same work in his early biographical account of Fuller, in which he described the artist as:

An English History-Painter of good Note. He had a great Genius for Drawing and Designing History, yet which he did not always execute with due Decency, nor after an Historical Manner, for he was too much addicted to Modernize, and burlesque his Subjects [...] notwithstanding all that a Critick may find fault with in his Works, there are many Perfections in them, as may be seen by his Resurrection at All-Souls-College, Chapel at Oxford [...] he may be reckon'd among the foremost in an account of English Painters. He studied many years in France under Perrier, and understood the Anatomical Part of Painting, perhaps equal to Michael Angelo, following it so close, that he was very apt to make the Muscelling too strong and prominent. (BUCKERIDGE 1706: 373-374)

The surviving fragments reveal the type of prominent musculature noted by Buckeridge, and also the nudity criticised by John Evelyn in 1664 when he described the work as "the largest piece of Fresco painting (or rather in Imitation of it, for tis in oyle [of Turpentine] in England, \& not ill-design'd" but also as one that "seemes too full of nakeds for a Chapell” (EVELYN 1901: 1: 377). Liversidge has pointed to Fuller's innovative place in 


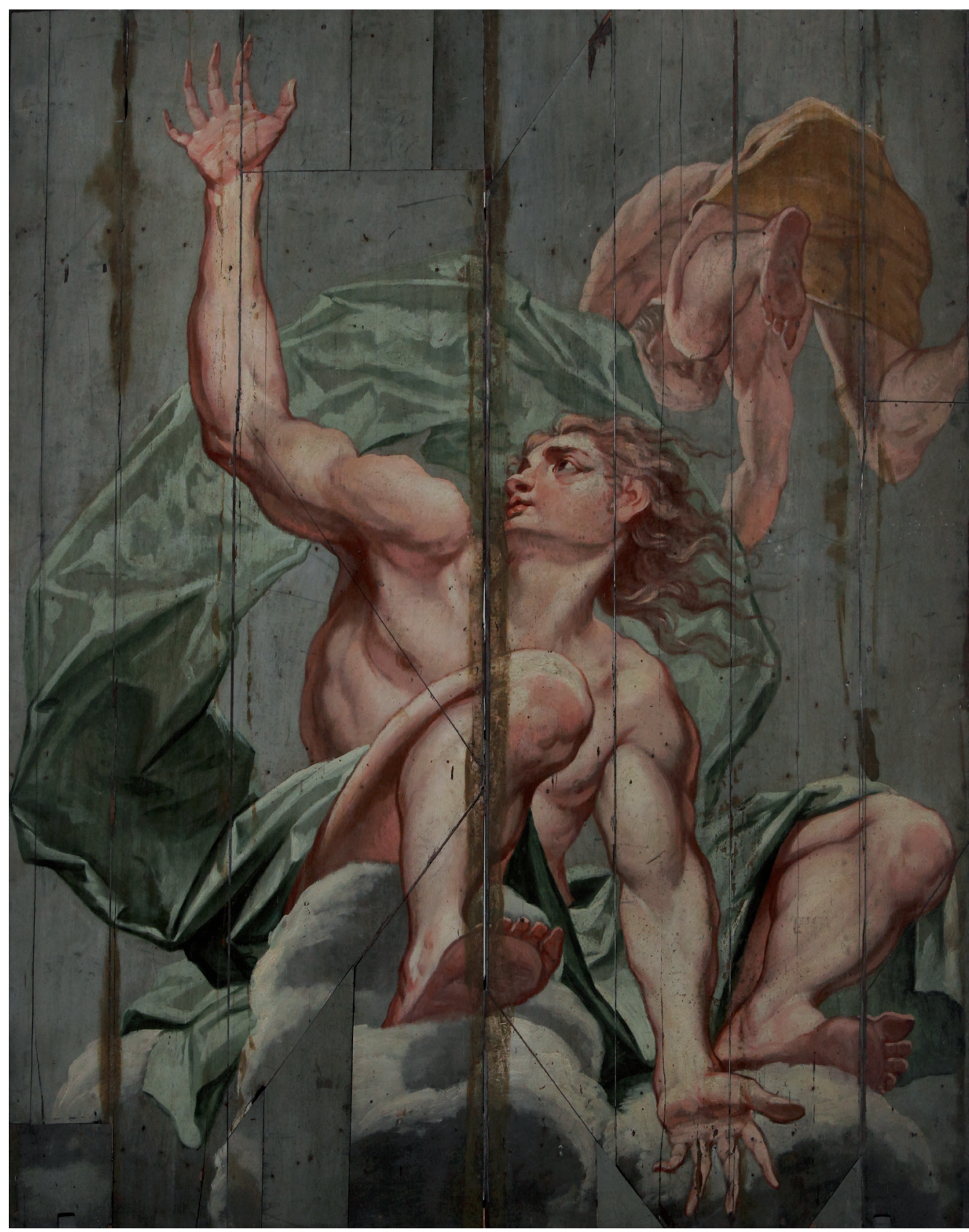

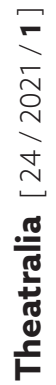

Fig. 2: Isaac Fuller, Resurrection (fragments), All Souls College, Oxford University. (c) The Warden and Fellows of All Souls College, Oxford. 


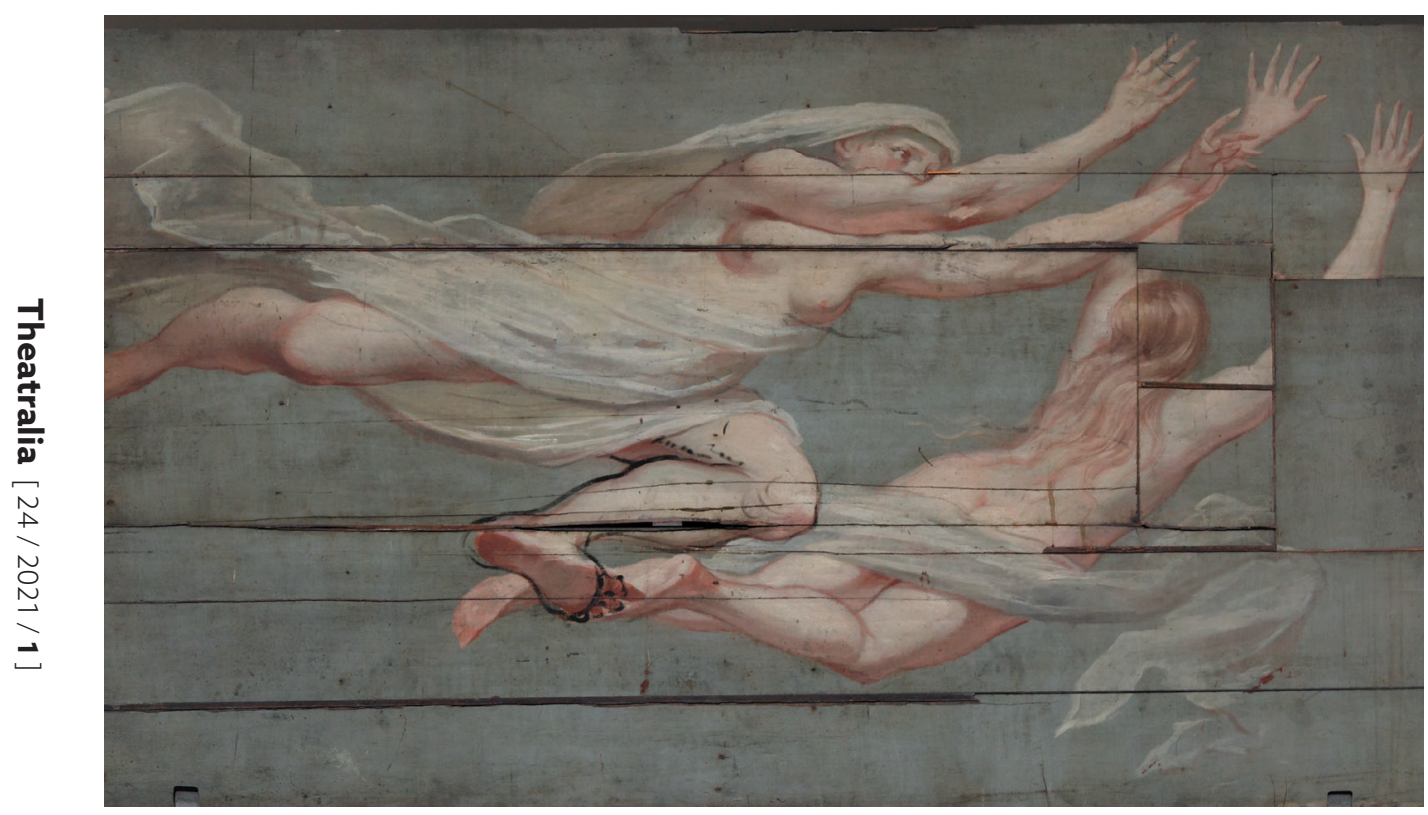

Fig. 3: Isaac Fuller, Resurrection (fragments), All Souls College, Oxford University. (c) The Warden and Fellows of All Souls College, Oxford.

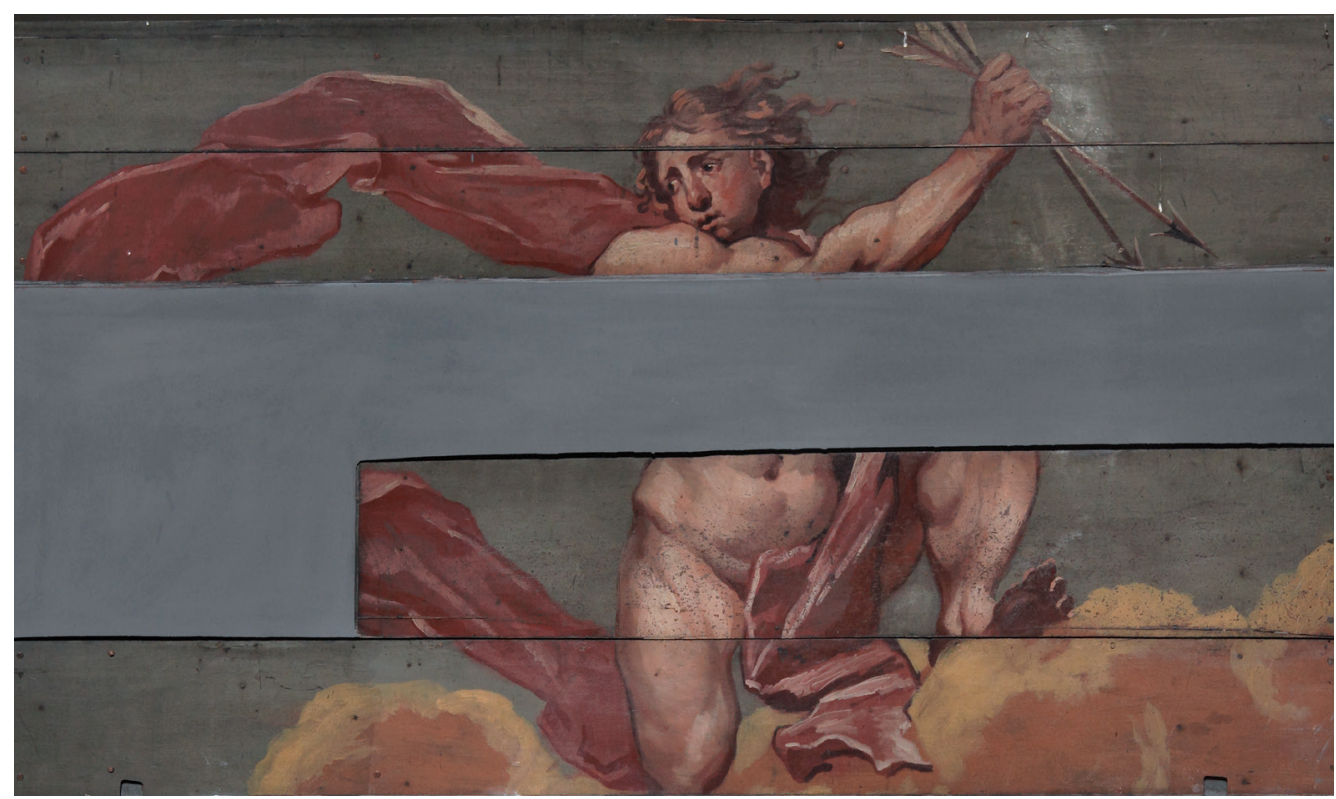

Fig. 4: Isaac Fuller, Resurrection (fragments), All Souls College, Oxford University.

(C) The Warden and Fellows of All Souls College, Oxford. 


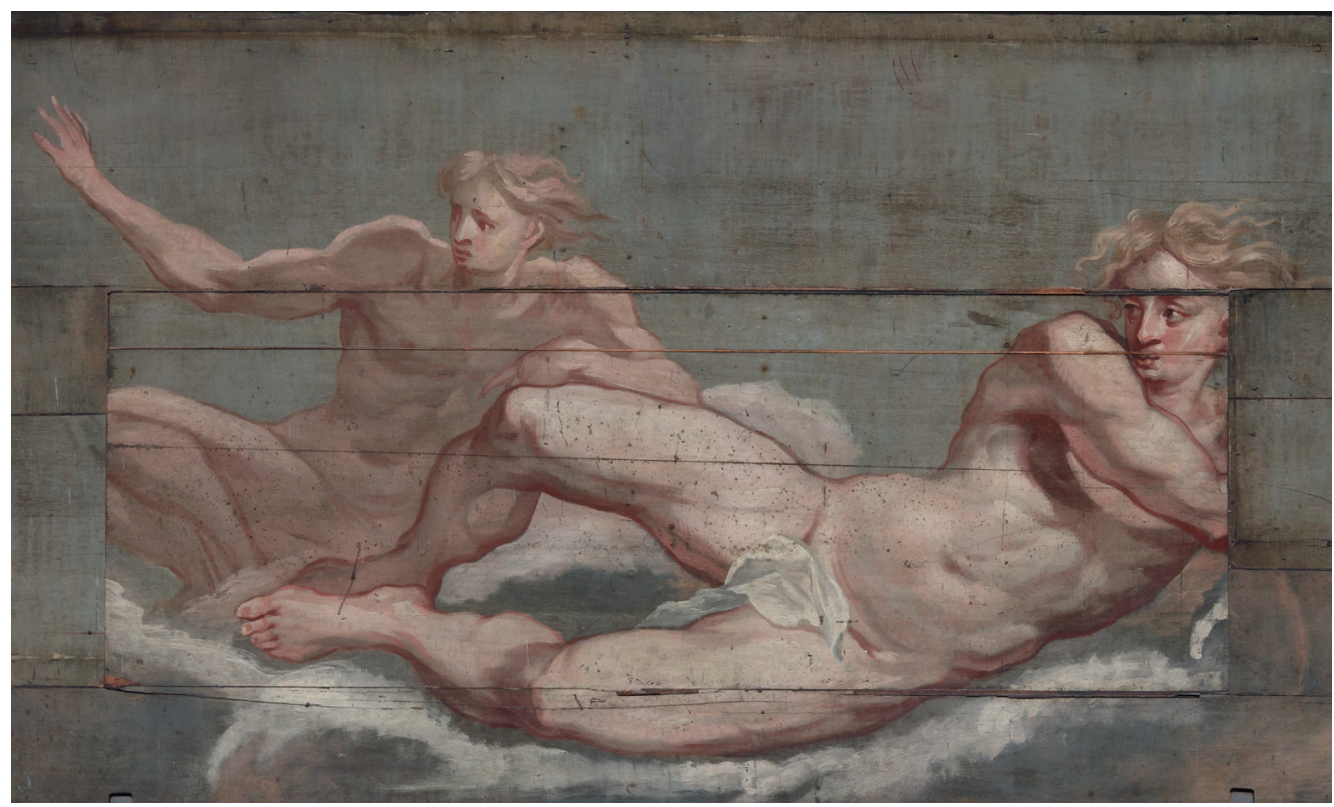

Fig. 5: Isaac Fuller, Resurrection (fragments), All Souls College, Oxford University.

(c) The Warden and Fellows of All Souls College, Oxford.

British art history: his work at All Soul's College must "have been one of the first examples in England in which a whole interior was treated decoratively in the baroque idiom as a single spatial and thematic entity" (LIVERSIDGE 1992: 324). Whilst it is difficult to reconstruct the complete scheme at All Souls from these fragments, other evidence from Fuller's work at Oxford survives in the form of later sketches of a decorative scheme for above the altarpiece at Magdalene College; surviving records in the college's accounts show that he was paid $£ 31310$ s for the work. As at the theatre, payment was settled ultimately through a legal dispute in which Fuller was successful (LIVERSIDGE 1992: 318). In summary, to gain a sense of the quality of the design and execution of the Elysium for Tyrannick Love, we might find a useful context in Fuller's wider work as a painter of decorative scenes and histories. This context suggests that the monies paid for the Elysium were on a par with those paid for decorative paintings in royal palaces and Oxford college chapels, and included a similar investment in the artist's time.

\section{Fuller's Fellow Scene Painters: Robert Streater \& Robert Robinson}

The connection between decorative painting and painted scenes for the stage is also seen in the careers of Fuller's contemporary artists Robert Streater [Streeter] (1621-1679) and Robert Robinson (1651-1706). A brief overview of the connection between their theatrical and wider decorative schemes enables us to further perceive the related nature of these outputs and how work for each milieu mutually informed the other. Streater, we 
may recall, was called as a witness for the plaintiffs in Fuller's Chancery case, yet his evidence ultimately supported Fuller's cause. In calling Streater as a witness, Killigrew and the Company were attempting to gain the support of the nation's leading expert in this arena. Streater was appointed Serjeant Painter to the King in 1663, and in 1665 painted the scenes in the Hall Theatre at Whitehall. Soon after the Chancery case he painted the scenes for the 1671 court performance of Dryden's Conquest of Granada. John Evelyn admired Streater's work on these scenes, noting that: "[n]ext day was acted there [Whitehall Theatre] the famous play, called, 'The Siege of Granada,' two days acted successively; there were indeed very glorious scenes and perspectives, the work of Mr. Streeter, who well understands it" (EVELYN 1901: 2: 62). Sybil Rosenfeld has summarised the records of Streater's work for the court theatre at Whitehall in the 1670s, including an account of the production of John Crowne's masque Calisto (1675) which provides "the only details we have of scene construction in the period" (ROSENFELD 1973: 51). These accounts again offer interesting comparative material when it comes to the financial side of painted scenes: Streater was paid $£ 5$ and $£ 20$ respectively for a pair of shutters and four pairs of wings of boscage [woods] for the Queen's masque in 1671. Again, this evinces the huge investment of Killigrew and the King's Company in Fuller's painted Elysium.

As with Fuller, Streater has been the attention of little wider research despite his prominence in his day. Yet happily, Streater's most celebrated work does survive: the painted ceiling of Wren's Sheldonian Theatre in Oxford (Fig. 6) - completed on canvas at Whitehall in 1668/9, then shipped by barge to Oxford where it was fixed into position in 1669. In Streater's scheme at the Sheldonian we are able, perhaps, to glimpse the type of decorative scheme and design that would have been employed for the best stage scenery. As Anthony Geraghty has evidenced in some detail, the Sheldonian Theatre ceiling was highly influenced by the genre of the court masque and by the work, and surviving sketches, of Inigo Jones. In his excellent analysis of Streater's scheme, Geraghty argues that the ceiling "exemplifies the close relationship that existed in the early Restoration period between painting, theatre and monarchy" (GERAGHTY 2013: 75). Streater's composition is overlaid with a series of gilded wooden cords (hiding the joins of his canvases), emulating the role of such cords in a Classical theatre design in which they would have been used to support a protective awning - a velarium - over the stage. Streater himself had stained the cords that supported the actual velarium at the Whitehall Theatre. But as Geraghty notes, it is the "visual language of the ceiling, however, that most obviously alludes to the Stuart masques of the pre-Civil War period" (GERAGHTY 2013: 79). The ceiling's subject matter is "the essential theme of all masques: the cosmic battle of moral abstractions, and the personification of these abstractions as allegorical characters/ figures (Truth and Learning vs. Envy, Rapine and Ignorance)" (GERAGHTY 2013: 77). Geraghty productively compares the ceiling's design with Jones's last great Stuart masque, Salmacida Spolia, performed at Whitehall in 1640. In the masque, the players first descend from a seat on a bank of clouds in the heavens to the stage, and later from the stage to join the audience in the pit where they reveal their true identities and participate in a dance. At the Sheldonian, this sense of descent is created by 


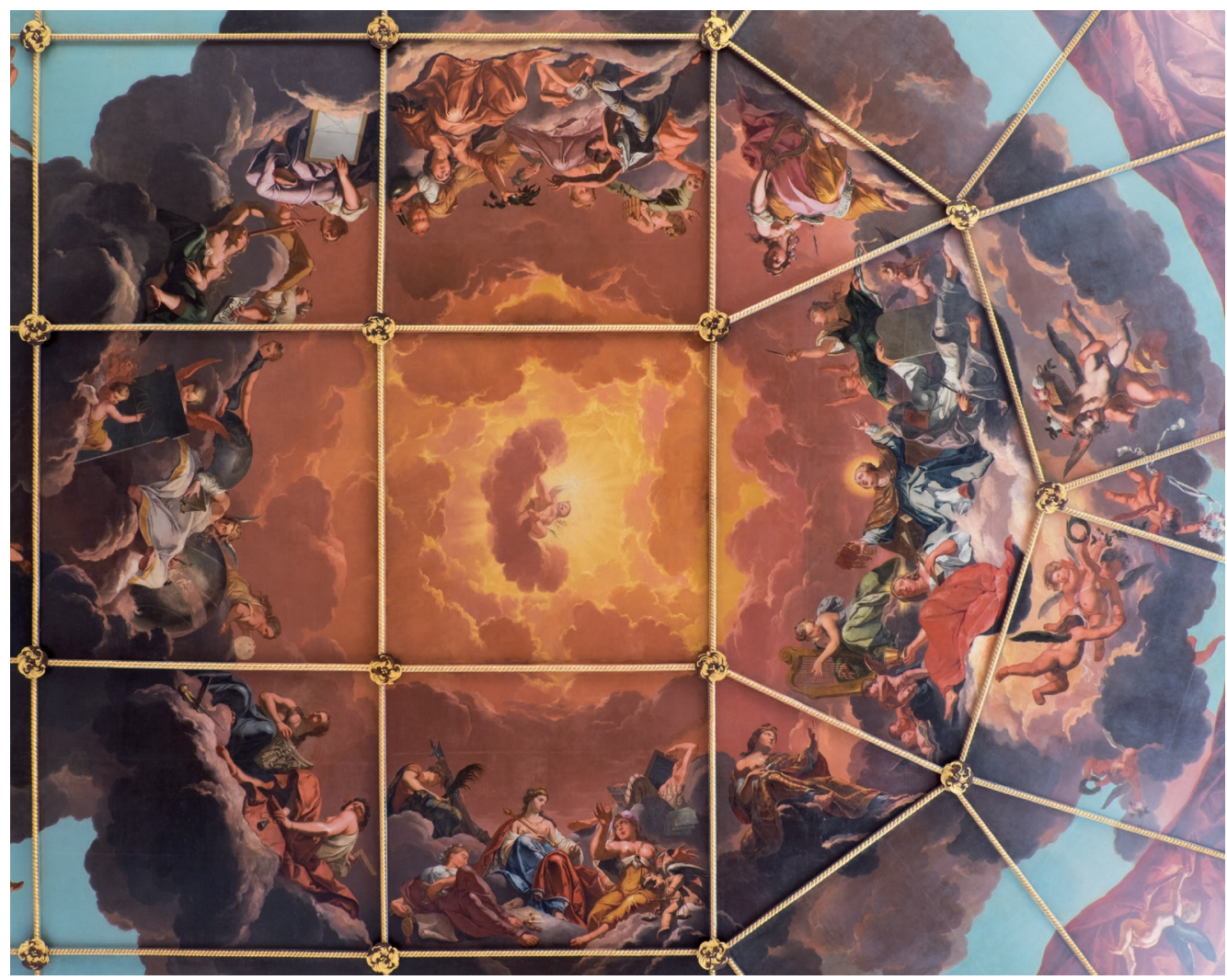

Fig. 6: Robert Streater, Ceiling fresco centrepiece (1670), Sheldonian Theatre, University of Oxford. (c) DeFacto.

the three anti-virtues who are painted using a dramatic foreshortening which makes them appear to be tumbling from the sky. Indeed, surviving sketches of Jones's set design for Salmacida Spolia depict a figure of Discord who, as Geraghty shows, holds a clear visual correspondence with the figure of Streater's Envy (79).

The influence of the court masque on Streater's design for the Sheldonian makes clear the close relationship between painting for the stage and for other architectural spaces. Whilst it may be easy to dismiss the idea that leading artists never undertook similar work for stage scenery, the identities of these artists, and the monies and time involved, surely meant that they were aiming to deliver something beyond rudimentary scenes. Nicolls suggests that in thinking about theatre scenery, "we may suspect that they [the artists] were all influenced by the scenic devices of the continent" (NICOLL 1923: 42). To an extent, of course, this must have been true since - as was the case with Fuller - much artistic training took place on the Continent. Yet artists like Streater and Fuller were also clearly influenced both by complementary forms of painting that they personally undertook elsewhere, as well as by other forms of creative expression in England. In Streater's case, the latter was the Caroline masque; in the case of his 
contemporary artist, Robert Robinson, it seems theatre production itself influenced the scenes he depicted in painting non-theatrical decorative interiors.

Even less research has been undertaken on Robert Robinson than on his contemporaries, Streater and Fuller. ${ }^{9}$ Little is known of Robinson's life or professional training, but he was a member of the Painter Stainer's Company, and we know he painted scenes for the theatre. The first record we have of such employment dates to the turn of the century, and Robinson's work for Elkanah Settle's opera The Virgin Prophetess, which premiered at the Theatre Royal in 1702. Yet it is clear that Robinson was influenced by contemporaneous theatrical production in some of his earlier decorative painting. Robinson's most celebrated surviving scheme - and only autographed work - is that of 'The Painted Room' designed and executed in a house at 32 Botolph Lane, London, around 1696, possibly for a West India Merchant (TRISTRAM 1913-1914: 75). The house later came into the possession of the John Cass Foundation, and when it was demolished in 1906 the 33 panels were moved to a nearby property in Duke Street, Aldgate, also belonging to the Foundation, where they were reinstalled in a slightly different scheme. As E. W. Tristram pointed out a century ago when he led the restoration of this work, the subject matter of this painted scheme is "extremely vague" in its depiction, but represents scenes associated with contemporaneous concepts of the exotic other: we find Chinese, Indian and West Indian influences, as well as portrayals of people from Europe, the Americas, Africa, Asia and the West Indies (TRISTRAM 1913-1914: 77). The dominant colour is green, with the rest of the scheme executed in a monochrome palette of yellows and browns. Coupled with the rich detail of the architecture and dress, this creates a sense of a colonial fairyland, replete with bejewelled princesses who wander through this magical realm attended by their slaves and servants (Fig. 7). This was a world that did not, of course, exist, and it is clear Robinson was working with a number of sources available to him in London. Tristram suggests these sources were traveller's accounts and the research of figures like Sir Hans Sloane (TRISTRAM 1913-1914: 77). More recently, Mireille Galinou has suggested the influence of Aphra Behn's novel Oroonoko (1688) on Robinson's work, especially in understanding the inclusion of such a range of skin tones in a single setting, and in the depiction of the activities of hunting, fishing and the pursuit of wild animals (GALINOU 2002: [5]).

I wish to argue that a further influence for Robinson's scheme is found in the form of the theatre, as mediated through mezzotint. William Vincent and John Smith's much celebrated engraving of Anne Bracegirdle in Dryden's 1695 play The Indian Princess (Fig. 8) is thought to depict the actress wearing a feathered dress brought back by Behn from her travels to Surinam, as recounted in Oroonoko (BEHN 1994: 7). When placed alongside Robinson's work for the "Painted Room", this mezzotint shares a significant correspondence with many of the princesses depicted in Robinson's scenes, not least the woman depicted on the panel bearing the artist's autograph (Fig. 7). Here, the composition of the figures (the central princess attended by two young slaves), many of the details of the dress and adornment, and the immediate landscape (of a cluster of 


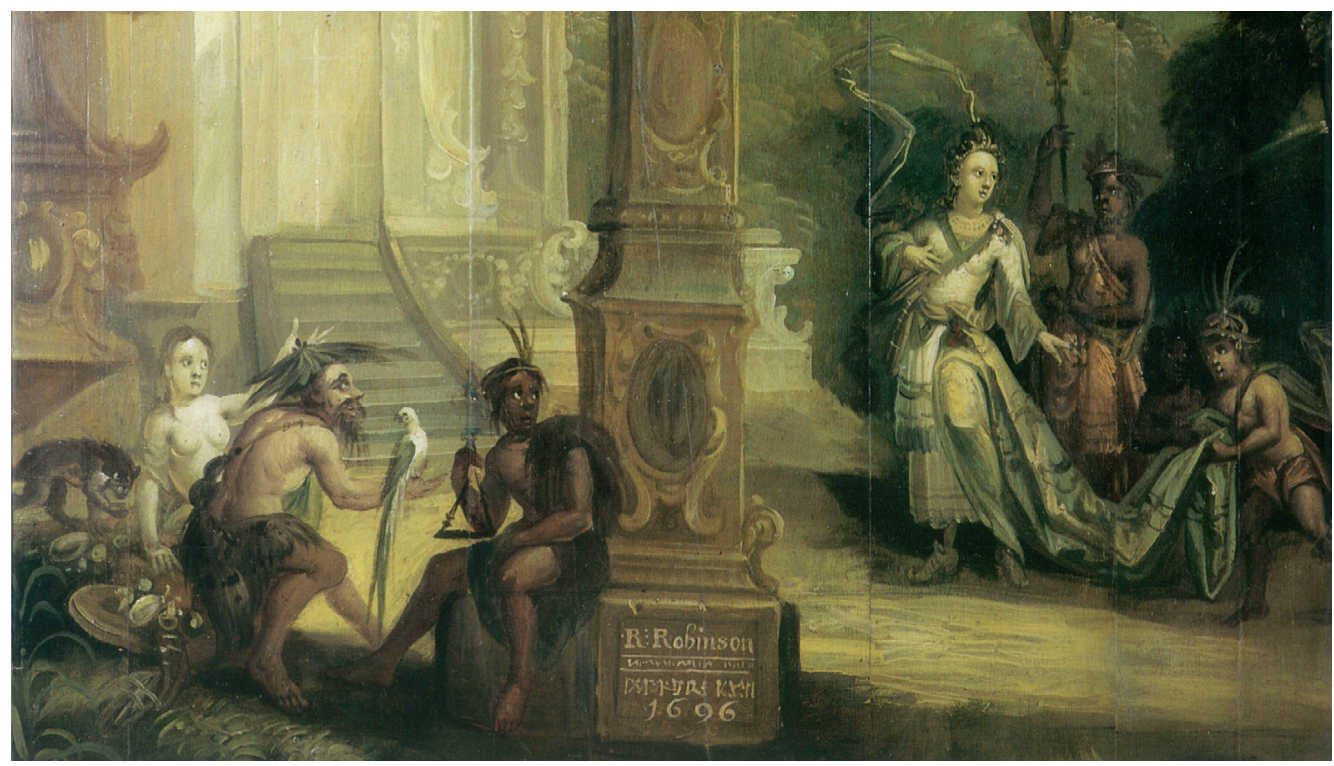

Fig. 7: Robert Robinson, detail from The Painted Room (1696).

(c) Sir John Cass Foundation, London.

trees, distant mountains, and clouds) are strikingly similar. Robinson certainly would have been aware of Smith and Vincent's print as he also worked as an engraver of mezzotints. A relatively new and experimental practice in the day, Smith was its leading practitioner in London during these years and the circle of those able to produce the medium was small.

Whilst it seems evident that Robinson was influenced by the mezzotint of Bracegirdle, we should question whether the influence of the play itself - and the theatre more widely - is present in works like his "Painted Room". Galinou observes that in Robinson's scheme the depicted world is one "dominated by women's power, beauty and quiet gravitas" (GALINOU 2002: [5]). In this sense, Robinson was depicting a world very much in dialogue with so many of the tragedies and operas popular on the stage throughout the Restoration, in which roles now performed by actresses took on increasing prominence. Robinson himself was later to be involved in painting scenes for at least one of these productions. A contract survives dating to 18 March 1700 showing that Robinson was to receive $£ 130$ within seven weeks for painting scenery for Settle's opera The Virgin Prophetess (MILHOUS and HUME 1991: 342). Again, there was a delay with the production as the opera did not premiere until May 1701. We do not know if this delay was caused by issues with the scenery. It is clear, however, that - as with Tyrannick Love - the scenery was a crucial feature of the play. The opening line of the prologue stresses the cost of the production: "This costly Play bears its proud Head so high, I As if your Smiles it some small Claim might buy" (SETTLE 1702: A2). This sentiment was echoed in an advertisement for the premiere placed in The Post Boy for 14-16 May 1700 which noted that: 


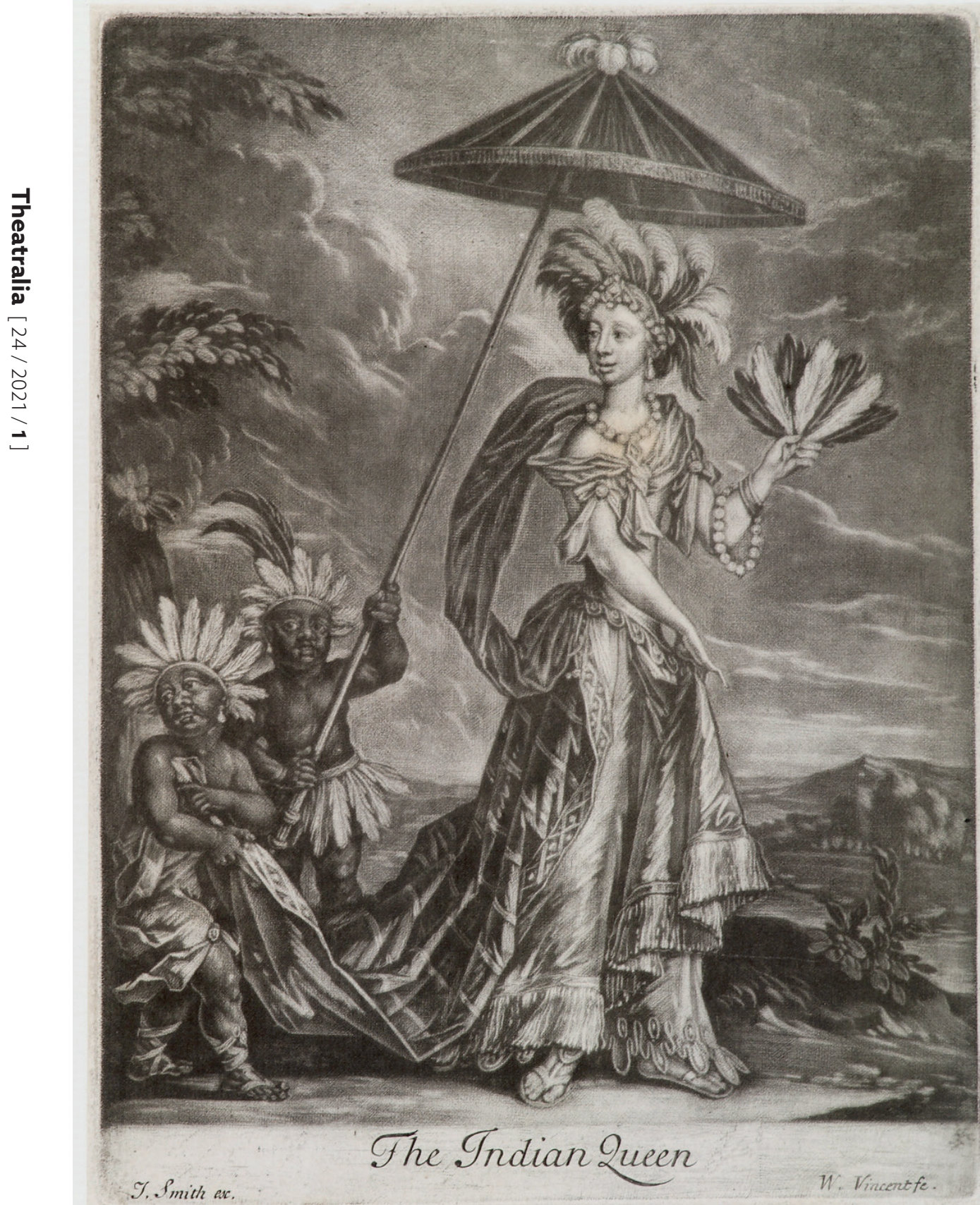

Fig. 8: "The Indian Queen" (Anne Bracegirdle), by William Vincent, published by John Smith (c. 1695), D19498. (c) National Portrait Gallery, London. 
Great Preparations have been making, for some Months past, for a New Opera to be Acted next Term at the Theatre Royal, which, for Grandeur, Decorations, Movements of Scenes, \&cc. will be infinitely superior to Dioclesian, which hitherto has been the greatest that the English Stage has produced, that probably 'twill equal the greatest Performance of that Kind, in any of the foreign Theatres. The Musick is compos'd by the Ingenious Mr. Finger, and the Paintings made by Mr. Robinson. (MILHOUS and HUME 1991: 344)

The advance advertising (of a year) for the production suggests there was some serious delay with the premiere. The advert is also interesting for the stress it places in using the names of the composer and painter involved with the production, rather than author or performers, as its chief means of promotion.

The stage directions printed for the opera certainly bear up the advertisement's stress on the complex and lavish nature of its scenery. There are thirteen directions that indicate substantial scene changes, with numerous special effects and diversions that are revealed within these main scenes of palaces, temples, cities, gardens and heavens. The first spectacular scene change comes early in the play, framing the entry of Paris and Helen in Act One:

The Curtain draws, and discovers the Town of Troy, with a Magnificent Chariot twenty Foot high, drawn by two White Elephants, placed in the Depth of the Prospect, between two triumphant Columns; the one bearing the Statue of Pallas, and the other of Diana, and fronting the Audience. In the Chariot are seated Paris and Helen; In the two front Entryes on each side of the Stage, advanced before the side Wings, are four more White Elephants, bearing, each a Castle on their Backs, with a Rich Canopy over each Castle, and in each three Women; on the necks of all the Elephants a Negro Guide. Each of these Paintings Twenty two Foot high. (SETTLE 1702: 5)

The directions here reveal a scene that corresponds closely with the types of scenes depicted in Robinson's "Painted Room" in which we see figures riding chariots pulled by elephants, rhinoceros, giraffes and gazelles. And as with the 'Painted Room', we see a preoccupation with the depiction of women as the prominent figures in the scene. This is later mirrored in other scenes of the play, for example in The Temple of Diana, used as the second setting for Act Two:

Within a Large Dome, are Erected five Pyramids, planted in a Cemicircle, each Pyramide Twenty two Foot high; at the Bottom of each Pyramide is a Pedestal five Foot and a half High; on each Pedestal stands a Figure (being so many young Women about 13 or 14 years of Age) drest in Cloth of Gold. (SETTLE 1702: 11)

The opera's painted scenes are so central to its success because Cassandra's prophetic power is shown by her ability to, quite literally, control the scene. For example, when Cassandra appeals to Diana to reveal Troy's fate in Act Two, the golden statues are transformed: "Here it Thunders, and immediately in a Moment, all the Golden Statues 
of the Goddesses are chang'd from Head to Foot into Black" (13). Robinson's surviving work in the "Painted Room" gives us a remarkable insight, then, into the very similar scenes he later created for the Theatre Royal's stage, albeit on a much larger scale. And the emphasis of Settle's opera on visual wonders, and their use in actively demonstrating Cassandra's powers, suggests why the theatre commissioned such a prominent artist to provide the scenes for this production.

\section{Conclusion}

Despite the publication of recent research on Restoration scenery, there remains much work to be done in recovering an accurate sense of the place and prominence of scenery in the public theatre. A century ago Nicoll suggested that "[w]hat exactly these scenes looked like, we can hardly tell now. In the majority of cases, they must have been crude enough, featuring a background rather than anything else" (NICOLL 1923: 40). In light of the evidence assembled in this article, this is an assessment that needs revisiting. Where the identity of artists involved in producing scenery for the public stage is known, the evidence increasingly points to the lavish complexity and skill likely involved in this work. For certain scenes, we know that the companies commissioned the leading artists of the day, whose work in producing decorative schemes meant they were masters of the arts of perspective. The scant decorative paintings by these artists that survive in other settings indicate a closer correlation between work for the theatre and these sites, as do extant financial and legal documents that detail their commission. Finally, analysis of play texts by Dryden and contemporaries reveals the crucial role that scenery could provide in producing the meaning of a play, making it wholly understandable why the companies would invest such great sums in certain scenes.

\section{Bibliography}

ARMISTEAD, Jack. 1988. Dryden and the Occult as Dramatic Code: Tyrannick Love. Papers on Language and Literature: A Journal for Scholars and Critics of Language and Literature 24 (1988): 4: 367-383.

BAKEWELL, Lyndsey. 2016. Changing Scenes and Flying Machines: Re-examination of Spectacle and the Spectacular in Restoration Theatre, 1660-1714. PhD dissertation. Loughborough University, 2016.

BEHN, Aphra. 1994. Oroonoko and Other Writings. Edited by Paul Salzman. Oxford: Oxford University Press, 1994.

BUCKERIDGE, Bainbrigge. 1706. An Essay Towards an English School of Painters. In R. de Piles. The Art of Painting, and the Lives of the Painters. London: J. Nutt, 1706: 398-480.

CROFT-MURRAY, Edward. 1962. Decorative Painting in England 1537-1837: Vol. One: Early Tudor to Sir James Thornhill, 2 vols. London: Country Life, 1962. 
DOWNES, Kerry. 1960. Fuller's 'Last Judgement.' The Burlington Magazine 102 (1960): 691: 450452.

DRYDEN, John and HOWARD, John. 1665. 'The Indian-Queen: A Tragedy'. Four New Plays. London: Henry Herringman, 1665: [137]-175.

EVELYN, John. 1901. The Diary of John Evelyn. 2 Vols. William Bray (ed.). London: M. Walter Dunn, 1901.

FLECKNOE, Richard. A Short Discourse of the English Stage. London: 1664.

GANZ, James Atkins. 2000. Robert Robinson (1651-1706): Painter-Stainer and Peintre Graveur. PhD dissertation, Yale University, 2000.

GALINOU, Mireille. 2002. The Painted Room: Sir John Cass's Foundation Primary School. London: Corporation of London, 2002.

GERAGHTY, Anthony. 2013. The Sheldonian Theatre: Architecture and Learning in SeventeenthCentury Oxford. New Haven/London: Yale UP, 2013.

HAMLETT, Lydia. 2020. Mural Painting in Britain 1630-1730: Experiencing Histories. London/ New York: Routledge, 2020.

KEENAN, Tim. 2017. Restoration Staging, 1660-74. London/New York: Routledge, 2017.

LIVERSIDGE, M. J. H. 1992. Prelude to the Baroque: Isaac Fuller at Oxford. Oxoniensia 57 (1992): 311-329.

MILHOUS, Judith. 1984. The Multimedia Spectacular on the Restoration Stage. In Shirley Strum Kenny (ed.). British Theatre and the Other Arts, 1660-1800. London: Associated University Presses, 1984: 41-62.

MILHOUS, Judith and Robert D. HUME. (eds.). 1991. A Register of English Theatrical Documents 1660-1737, Vol. 1 1660-1714. (Southern Illinois UP, 1991).

NICOLL, Allardyce. 1923. History of English Drama. Cambridge: Cambridge UP, 1923.

NOVAK, Maximillian E. Novak and George Robert GUFFEY (eds.). 1970. Works of John Dryden: Vol. X. Berkeley: Uni of California Press, 1970.

ROGERS, Malcolm. 1979. Isaac Fuller and Charles II's escape from the Battle of Worcester. Connoisseur (1979): 164-169.

ROSENFELD, Sybil. 1973. A Short History of Scene Design in Great Britain. Oxford: Basil Blackwell, 1973.

SETTLE, Elkanah. 1702. Cassandra: Or, The Virgin Prophetess, An Opera. London, 1702.

SOLKIN, David. 1999. Isaac Fuller's Escape of Charles II: a Restoration tragicomedy. Journal of the Warburg and Courtauld Institutes 62 (1999): 199-240.

TRISTRAM, E. W. 1913-1914. A Painted Room of the Seventeenth Century. The Volume of the Walpole Society 3 (1913-1914): 75-81.

WRIGHT, James. 1699. Historia Histrionica. London, 1699. 
The "Scaene of Elysium": Painters, Plaintiffs and Paradise in John Dryden's Tyrannick Love (1669)

\section{Dr Claudine van Hensbergen}

Department of Humanities, Northumbria University, Newcastle-upon-Tyne, NE1 8ST, United Kingdom

claudine.vanhensbergen@northumbria.ac.uk

Claudine van Hensbergen is Associate Professor in Eighteenth-Century Literature at Northumbria University, and works on British literary and visual culture of the 1660s to the 1730s. She is volume editor (Vol. 3) of The Plays and Poetry of Nicholas Rowe (2017) and has co-edited journal special issues on Queen Anne and British culture (JECS, 2014) and the eighteenth-century letter (Eighteenth-Century Life, 2011). Claudine is currently an AHRC Leadership Fellow on the project 'Learning through the Art Gallery: Art, Literature \& Disciplinarity' and preparing a monograph, The Making of Monument in Britain, 1660-1720. 